\title{
Changes related to the oestrous cycle in the expression of endometrial and oviductal proteins of mice
}

\author{
B. Horvat ${ }^{1}$, H. Vrčić ${ }^{2}$ and I. Damjanov ${ }^{1 *}$ \\ ${ }^{1}$ Department of Pathology and Cell Biology, Jefferson Medical College, Thomas Jefferson \\ University, Philadelphia, Pennsylvania 19107, USA; and ${ }^{2}$ The Department of Obstetrics and \\ Gynecology, University of Zagreb, School of Medicine, Zagreb, Yugoslavi.
}

\begin{abstract}
Summary. Soluble proteins extracted from the endometria and oviducts of normal sexually mature cycling Swiss Webster mice were analysed by two-dimensional highresolution sodium dodecyl sulfate polyacrylamide gel electrophoresis (SDS-PAGE). Thirty endometrial and 25 oviductal proteins showed differential expression related to the oestrous cycle. In the endometrium, 19 proteins were maximally expressed in the oestrous phase, and significantly decreased or could not be detected in dioestrus. Eleven additional proteins were more prominent in dioestrus. Most of these endometrial cyclic proteins were acidic. In the oviduct, almost two-thirds of cycle-related, differentially expressed proteins were more strongly expressed in dioestrus and were significantly less prominent or could not be detected in the oestrous phase. In contrast to the endometrial proteins, most of the oviductal cyclic proteins were basic. Fourteen proteins appeared to be identical in both organs, and five of these showed the same cyclic pattern of expression. The remaining cyclic proteins were organ specific and showed uterus- or oviduct-specific changes during the oestrous cycle. Among the cyclic proteins, four endometrial and two oviductal proteins were restricted to oestrus, whereas two endometrial and seven oviductal proteins were restricted to dioestrus. These proteins could serve as markers for specific phases of the oestrous cycle. Our data show that the mouse oestrous cycle is associated with consistent and predictable changes in protein expression in both the endometrium and oviduct.
\end{abstract}

Keywords: proteins; endometrium; oviduct; mouse; oestrous cycle

\section{Introduction}

The oestrous cycle of the mouse has been described morphologically (Allen, 1922) and its hormonal basis has been defined in numerous studies (Michael, 1976; Murr et al., 1973; DeLeon et al., 1990). However, there are no data on changes in uterine proteins during the cycle. Most of the available data relate to secretory proteins (Gore-Langton \& Surani, 1976) and lactotransferrin is the major oestrogen-induced secretory uterine product (Teng et al., 1986; Pentecost \& Teng, 1987). The effects of exogenous sex hormones on the expression of uterine proteins were studied by Quarmby $\&$ Korach (1984). Studies have also been performed on pregnancy-associated changes in uterine secretions of mice (Fishel, 1979, 1980). Secretory proteins from uteri at the time of implantation have been studied by Weitlauf \& Suda-Hartman (1988). However, in these studies no distinction was made between the various phases of the normal oestrous cycle. There are few reports on mouse oviductal proteins and these are limited to secretory proteins (Nieder \& Macon, 1987). The 215 kDa glycoprotein of early pregnancy identified by Kapur \& Johnson $(1985,1986,1988)$ has been studied most extensively.

*Correspondence and reprint requests. 
Table 1. Analysis of cellular protein expression in mouse endometrium during different phases of the oestrous cycle by two-dimensional SDS-PAGE

\begin{tabular}{|c|c|c|c|c|}
\hline $\begin{array}{l}\text { Spot } \\
\text { number }\end{array}$ & $M_{\mathrm{r}}$ & $\mathrm{pI}$ & Oestrus & Dioestrus \\
\hline 1 & $25 \cdot 0$ & $7 \cdot 40$ & - & + \\
\hline 2 & $28 \cdot 0$ & $6 \cdot 80$ & + & - \\
\hline 3 & $29 \cdot 5$ & $7 \cdot 85$ & 0 & + \\
\hline 4 & $35 \cdot 0$ & $5 \cdot 60$ & - & + \\
\hline 5 & $37 \cdot 0$ & $7 \cdot 60$ & - & + \\
\hline 6 & $38 \cdot 5$ & $7 \cdot 60$ & - & + \\
\hline 7 & $39 \cdot 0$ & $6 \cdot 90$ & - & + \\
\hline 8 & $40 \cdot 0$ & $5 \cdot 25$ & - & + \\
\hline 9 & $41 \cdot 0$ & $5 \cdot 70$ & 0 & + \\
\hline 10 & $41 \cdot 5$ & $6 \cdot 75$ & + & 0 \\
\hline 11 & $44 \cdot 5$ & $7 \cdot 10$ & + & - \\
\hline 12 & $54 \cdot 0$ & $5 \cdot 40$ & - & + \\
\hline 13 & $55 \cdot 0$ & $6 \cdot 30$ & + & - \\
\hline 14 & $57 \cdot 0$ & $7 \cdot 90$ & + & - \\
\hline 15 & 59.0 & $4 \cdot 80$ & + & - \\
\hline 16 & $60 \cdot 0$ & $4 \cdot 90$ & + & - \\
\hline 17 & $76 \cdot 0$ & $6 \cdot 75$ & - & + \\
\hline 18 & $78 \cdot 0$ & $4 \cdot 70$ & + & 0 \\
\hline 19 & $80 \cdot 0$ & 6.65 & - & + \\
\hline 20 & $85 \cdot 0$ & $5 \cdot 45$ & + & - \\
\hline 21 & $90 \cdot 0$ & $5 \cdot 20$ & + & - \\
\hline 22 & 96.0 & 7.90 & + & - \\
\hline 23 & $97 \cdot 0$ & 8.05 & + & - \\
\hline 24 & $104 \cdot 0$ & $6 \cdot 90$ & + & - \\
\hline 25 & $104 \cdot 0$ & 4.90 & + & - \\
\hline 26 & 115.0 & $7 \cdot 90$ & + & 0 \\
\hline 27 & $135 \cdot 0$ & $7 \cdot 80-8 \cdot 10$ & + & - \\
\hline 28 & $135 \cdot 0$ & $6.05-6.25$ & + & 0 \\
\hline 29 & $150 \cdot 0$ & $5 \cdot 15-5 \cdot 35$ & + & - \\
\hline 30 & $160 \cdot 0$ & $6 \cdot 00-6 \cdot 45$ & + & - \\
\hline
\end{tabular}

During our electrophoretic studies of uterine whole-cell extracts derived from normal sexually mature outbred mice we noticed considerable inter-sample variation. We hypothesized that these inconsistencies might be related to the normal hormonally induced changes that occur during the oestrous cycle. In this paper we report the results of our systematic study of endometrial and oviductal proteins in the oestrous and dioestrous phases of the cycle. We also show that cyclic changes occur not only in the uterus but also in the oviduct, albeit in a different form.

\section{Materials and Methods}

\section{Animals}

Virgin Swiss Webster mice (6-8 weeks old) were maintained on a regular photoperiod of $12 \mathrm{~h}$ light:12 h dark. Vaginal smears were taken every morning and classified according to standard cytological criteria (Bronson et al., 1968). Only mice demonstrating three consecutive oestrous cycles were used. In such regularly cycling mice the vaginal smears consistently reflect the histological changes in the uterus (Putti \& Varano, 1979). Groups of 3-4 mice in the same phase were killed in the oestrous or dioestrous phase of the normal oestrous cycle (Rugh, 1968). 


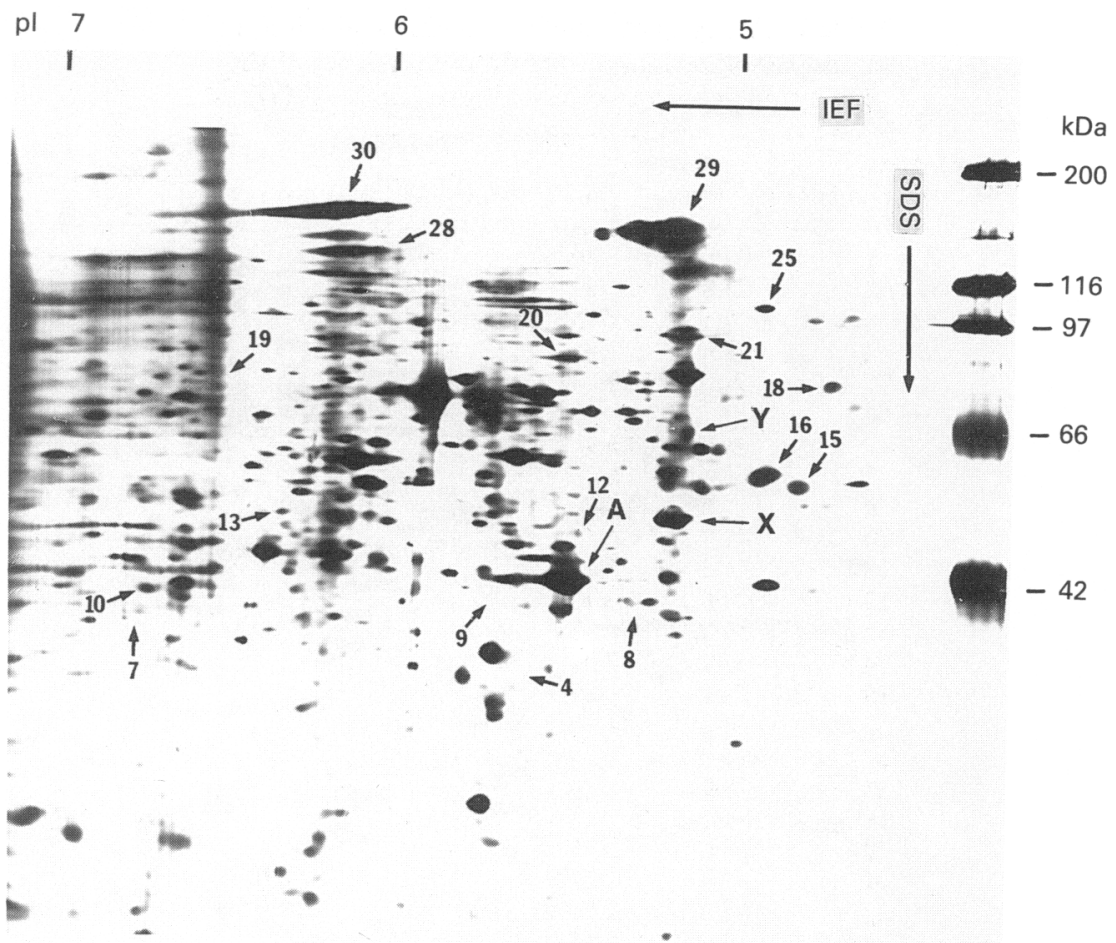

Fig. 1. Oestrous-phase endometrial proteins separated by isoelectric focusing (IEF), pH 5-7. Arrows indicate the proteins that showed cyclic changes. Specific cellular proteins: A, actin $\left(M_{\mathrm{r}}\right.$ 45000 , pI 5-40-5.44); X, $\alpha$-tubulin ( $M_{\mathrm{r}} 55000$, pI 5-20); Y, $\beta$-tubulin ( $M_{\mathrm{r}} 65000$, pI 5·20).

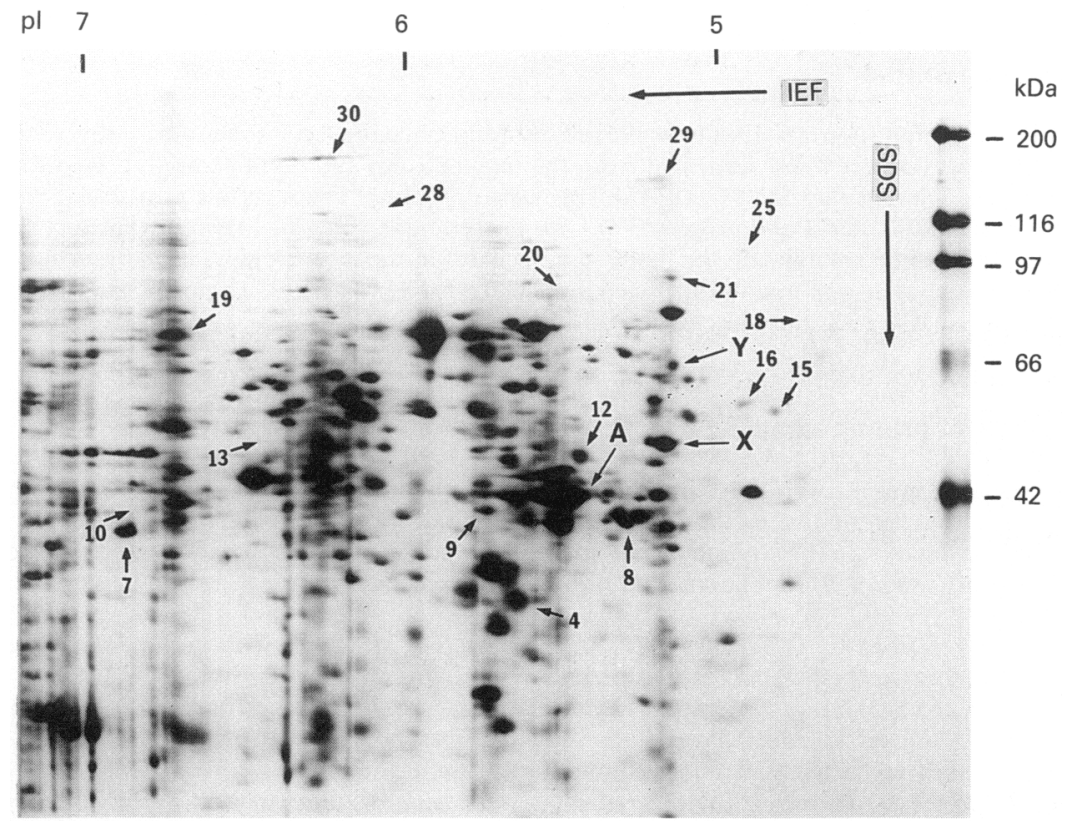

Fig. 2. Dioestrous-phase endometrial proteins separated by isoelectric focusing (IEF), pH 5-7. Arrows indicate the proteins that showed cyclic changes. Specific cellular proteins: A, actin $\left(M_{\mathrm{r}}\right.$ 45000 , pI 5.40-5.44); X, $\alpha$-tubulin ( $M_{\mathrm{r}} 55000$, pI 5.20); Y, $\beta$-tubulin ( $M_{\mathrm{r}} 65000$, pI 5.20). 


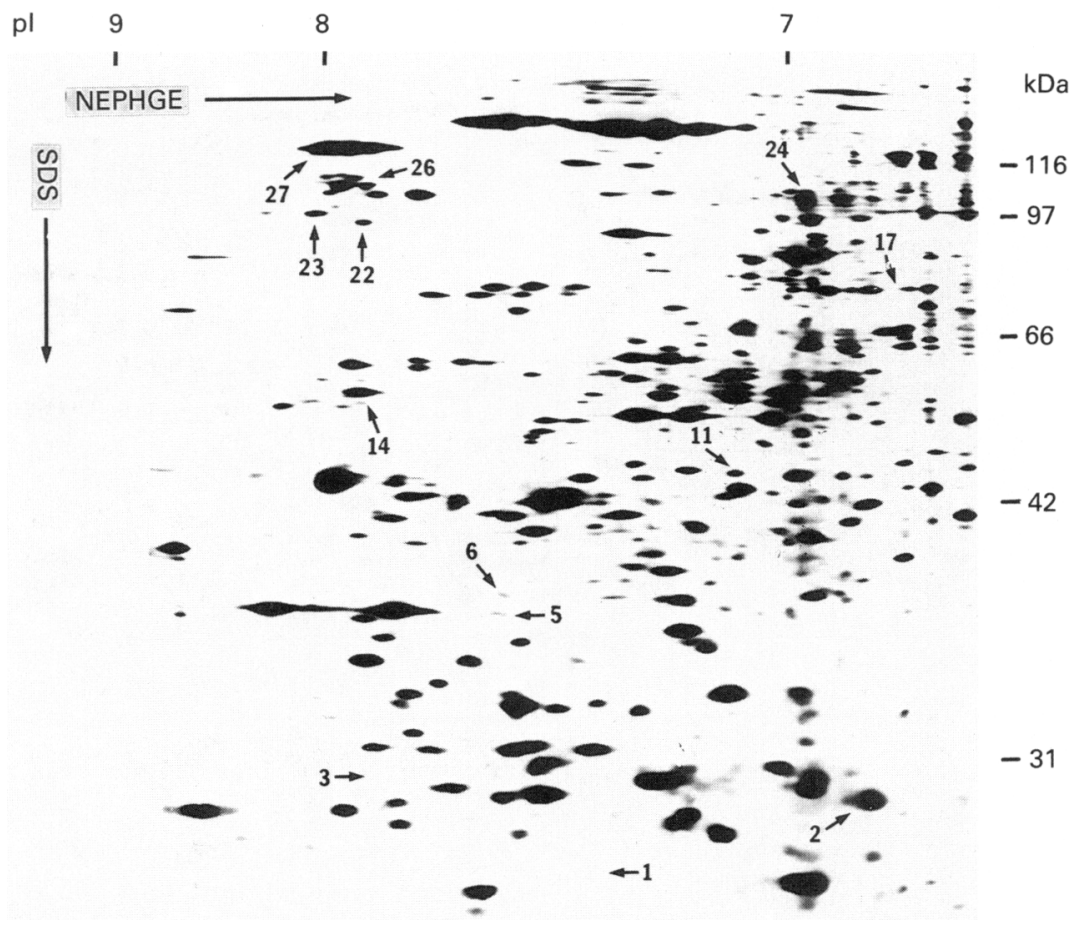

Fig. 3. Oestrous-phase endometrial proteins separated by nonequilibrium $\mathrm{pH}$ gradient electrophoresis (NEPHGE) pH 7-9. Arrows indicate the proteins that showed cyclic changes.

\section{Protein sample preparation}

Mice were killed by decapitation, and the uteri were removed and placed on ice. Uterine horns were slit longitudinally and the endometrium was scraped and separated from the myometrium and homogenized in cold PBS containing $0.1 \mathrm{~mol}$ phenylmethylsulphonyl fluoride $\mathrm{1}^{-1}$ (PMSF) protease inhibitor. Oviducts were dissected from the tuboovarian sac, severed from the uterus and processed in toto. Each sample contained tissues from four to six animals. The samples were prepared by solubilizing the tissue homogenates in the isoelectric focusing lysis buffer (O'Farrell, 1975). Dissolved homogenates were microcentrifuged at $14000 \mathrm{~g}$ for $15 \mathrm{~min}, 4^{\circ} \mathrm{C}$. The pellet was discarded and the supernatants were stored at $-80^{\circ} \mathrm{C}$ until electrophoretic analysis.

\section{Gel electrophoresis of protein samples}

The protein content of samples were measured according to the method of Lowry et al. (1951), using bovine serum albumin as standard. Two alternative methods of two-dimensional SDS-PAGE were used: first, the combination of standard isoelectric focusing (IEF, nominal $\mathrm{pH}$ range 5-7) and nonequilibrium $\mathrm{pH}$ gradient electrophoresis (NEPHGE, nominal $\mathrm{pH}$ range 7-9) for endometrial proteins, and second, NEPHGE with nominal $\mathrm{pH}$ range 3.5-10 for oviductal proteins.

We used methods described by O'Farrell (1975) and O'Farrell et al. (1977) with minor modifications. Protein standards of known molecular weight were obtained from Bio-Rad Laboratories (Richmond, CA, USA). Ampholines for first-dimension gels and IEF buffer were obtained from Pharmacia LKB (Gathersburg, MD, USA). IEF tube gels contained a mixture of $1.6 \% \mathrm{pH} \mathrm{5-7}$ and $0.4 \% \mathrm{pH} \mathrm{3.5-10}$ ampholines. NEPHGE tube gels contained $2 \% \mathrm{pH} 7-9$ and $2 \% \mathrm{pH} 3 \cdot 5-10$ ampholines, respectively. Samples containing $150 \mu \mathrm{g}$ of total proteins were loaded on the top each tube gel $(3 \mathrm{~mm}$ in diameter, $10 \mathrm{~cm}$ long). The pI gradient of tube gels was measured on $5 \mathrm{~mm}$ gel sections. Electrofocused gels were equilibrated with Laemmli buffer for $2 \mathrm{~h}$ and stored at $-80^{\circ} \mathrm{C}$ (Laemmli et al., 1970). The seconddimension electrophoresis was performed on $12 \mathrm{~cm}$ long, $1.5 \mathrm{~mm}$ thick slab gels containing $10 \%$ acrylamide with a $2.5 \%$ stacking gel. After the electrophoresis, gels were fixed in $50 \%$ methanol overnight. Proteins were visualized by silver staining using the silver-staining kit obtained from Accurate (Westbury, NY, USA). 


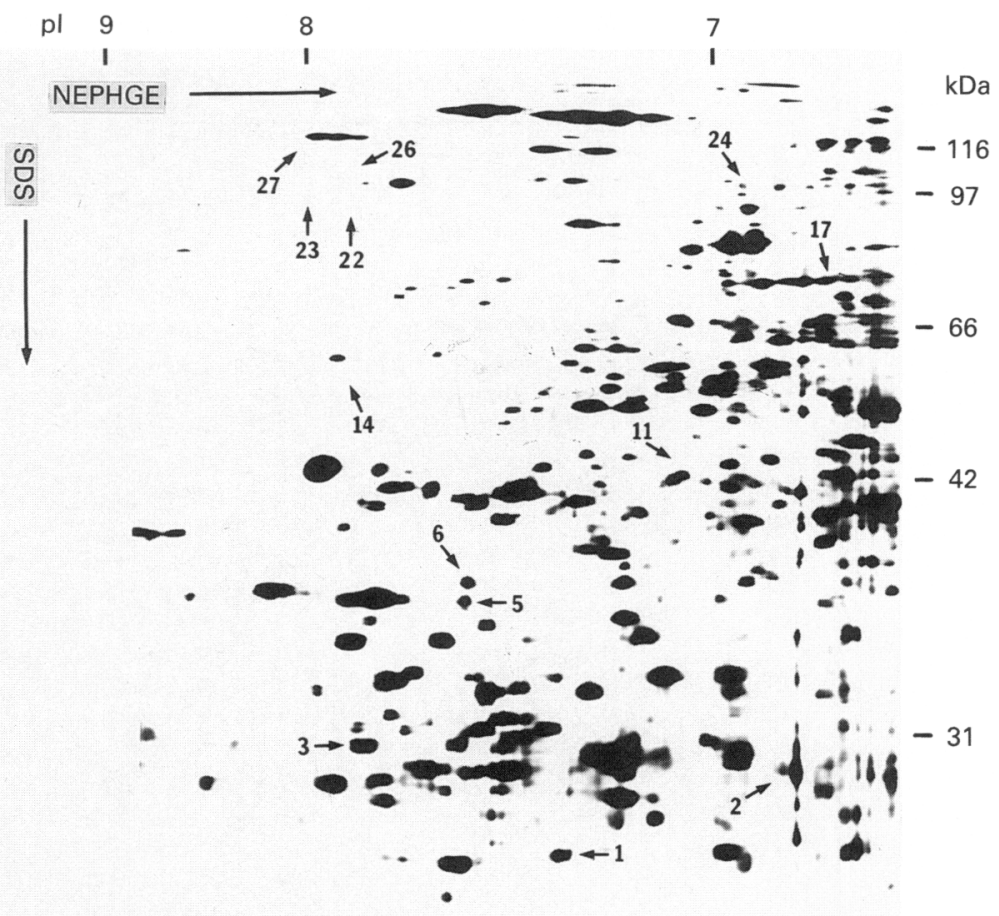

Fig. 4. Dioestrous-phase endometrial proteins separated by nonequilibrium $\mathrm{pH}$ gradient electrophoresis (NEPHGE) pH 7-9. Arrows indicate the proteins that showed cyclic changes.

\section{Analysis of two-dimensional gels}

Three to four gels from each phase were prepared. Only protein spots showing obvious and consistent cyclicity were considered phase specific. The comparison of endometrial with oviductal proteins and the protein patterns obtained in the present study with previously published data was based on three specific features: the relative molecular weight of the protein $\left(M_{\mathrm{r}}\right)$, its isoelectric point $(\mathrm{pI})$ and grouping of spots or pattern of neighbouring spots and their relation to constant markers such as actin and tubulins. $\mathrm{pH}$ gradient graphs, plots of the measured $\mathrm{pH}$ values of gel sections against the distance from the cathode end of the tube gel, were used to determine the approximate pI values for each protein. The calculated $\mathrm{pI}$ values varied slightly more from one gel to another than did the $M_{\tau}$ values. However, the overall protein patterns were relatively constant for each phase of the cycle in both organs and the precise location of the cyclic proteins could be confidently determined.

\section{Results}

Owing to the abundance of proteins in the mouse endometrium and oviduct, the conditions of two-dimensional SDS-PAGE had to be varied to define the difference related to the oestrous cycle in the expression of proteins. In our initial experiments we used NEPHGE with a broad pH range $(3 \cdot 5-10)$, which allowed us to identify up to 500 spots. Although this method was sufficient for the separation of oviductal extracts, it was found inadequate for the clear resolution of endometrial extracts, which contained more proteins. The acidic and basic endometrial proteins were therefore analysed separately, using IEF with a pH range 5-7 and NEPHGE pH 7-9. Using this approach, it was possible to resolve about 700 individual endometrial protein spots. Not all of these spots are visible in the underexposed photographs included in this paper. For practical reasons we describe only the most obvious proteins that are differentially expressed in the oestrogen- and progesteronedominated phases of the oestrous cycle, i.e. oestrus and dioestrus. 
Table 2. Analysis of cellular protein expression in mouse oviduct during different phases of the oestrous cycle by two-dimensional SDS-PAGE

\begin{tabular}{|c|c|c|c|c|}
\hline $\begin{array}{l}\text { Spot } \\
\text { number }\end{array}$ & $M_{\mathrm{r}}$ & $\mathrm{pI}$ & Oestrus & Dioestrus \\
\hline I & $29 \cdot 5$ & $7 \cdot 85$ & - & + \\
\hline 2 & $31 \cdot 0$ & $8 \cdot 25$ & 0 & + \\
\hline 3 & $31 \cdot 5$ & $8 \cdot 40$ & - & + \\
\hline 4 & $31 \cdot 5$ & $7 \cdot 75$ & 0 & + \\
\hline 5 & 33.0 & $7 \cdot 80$ & - & + \\
\hline 6 & $33 \cdot 5$ & $6 \cdot 75$ & - & + \\
\hline 7 & $35 \cdot 0$ & $7 \cdot 50$ & 0 & + \\
\hline 8 & $35 \cdot 0$ & $4 \cdot 60$ & + & 0 \\
\hline 9 & $35 \cdot 5$ & $8 \cdot 45$ & + & - \\
\hline 10 & 36.0 & $8 \cdot 40$ & 0 & + \\
\hline 11 & $36 \cdot 0$ & $8 \cdot 25$ & 0 & + \\
\hline 12 & $36 \cdot 5$ & $8 \cdot 10$ & - & + \\
\hline 13 & $37 \cdot 0$ & $7 \cdot 80$ & 0 & + \\
\hline 14 & $37 \cdot 0$ & $5 \cdot 65$ & 0 & + \\
\hline 15 & $37 \cdot 0$ & $4 \cdot 60$ & + & - \\
\hline 16 & $38 \cdot 0$ & $4 \cdot 60$ & + & 0 \\
\hline 17 & $38 \cdot 0$ & 4.95 & - & + \\
\hline 18 & $47 \cdot 0$ & $8 \cdot 75$ & + & - \\
\hline 19 & $57 \cdot 0$ & $7 \cdot 90$ & + & - \\
\hline 20 & 86.0 & $6 \cdot 40$ & - & + \\
\hline 21 & $87 \cdot 0$ & 5.95 & + & - \\
\hline 22 & $103 \cdot 0$ & $5 \cdot 35$ & - & + \\
\hline 23 & $135 \cdot 0$ & $8 \cdot 20$ & + & - \\
\hline 24 & $135 \cdot 0$ & $6 \cdot 15$ & + & - \\
\hline 25 & $150 \cdot 0$ & $7 \cdot 20-7 \cdot 95$ & + & - \\
\hline
\end{tabular}

In the endometrial extracts, 30 polypeptides were found to be differentially expressed in oestrus and dioestrus. Nineteen of these spots were more prominent in oestrus and were less apparent in dioestrus. Four of these 19 proteins (numbers 10, 18, 26, 28) could not be detected in dioestrus. Eleven of the 30 cyclic proteins were more evident during the dioestrus phase. Two of these proteins (numbers 3,9 ) were exclusively expressed in dioestrus and could not be detected in oestrus (Table 1 and Figs 1-4).

The analysis of oviductal cellular extracts defined a group of 25 proteins related to the oestrous cycle. Fifteen spots were most prominent during the dioestrous phase. Eight of these were less apparent in oestrus, while seven spots (numbers $2,4,7,10,11,13,14$ ) could not be detected in oestrus. Ten proteins showed maximal expression in oestrus. Eight of these were barely detectable in dioestrus, and two proteins (numbers 8,16 ) could not be detected at all in dioestrus (Table 2 and Figs 5 and 6).

Using the defined criteria, i.e. molecular weight, isoelectric point and local two-dimensional spot pattern, we have correlated endometrial and oviductal samples to identify presumptively identical proteins. Among the cycling proteins, 15 had identical electrophoretic characteristics, both in the endometrium and the oviduct. However, only five of these showed the same cyclic pattern in both organs (endometrial spot numbers $3,5,14,27,28$ related to oviductal spots $(1,13$, $19,23,24)$. In addition, six endometrial (numbers 4, 15, 16, 18, 29, 30) and four oviductal (numbers $4,5,14,25)$ cyclic proteins displayed organ-specific patterns of cyclicity, i.e. showed cyclic expression in only one of these organs. The remaining 19 of the 30 endometrial and 16 of the 25 oviductal proteins were considered organ specific and had no corresponding equivalents in the other organ. 


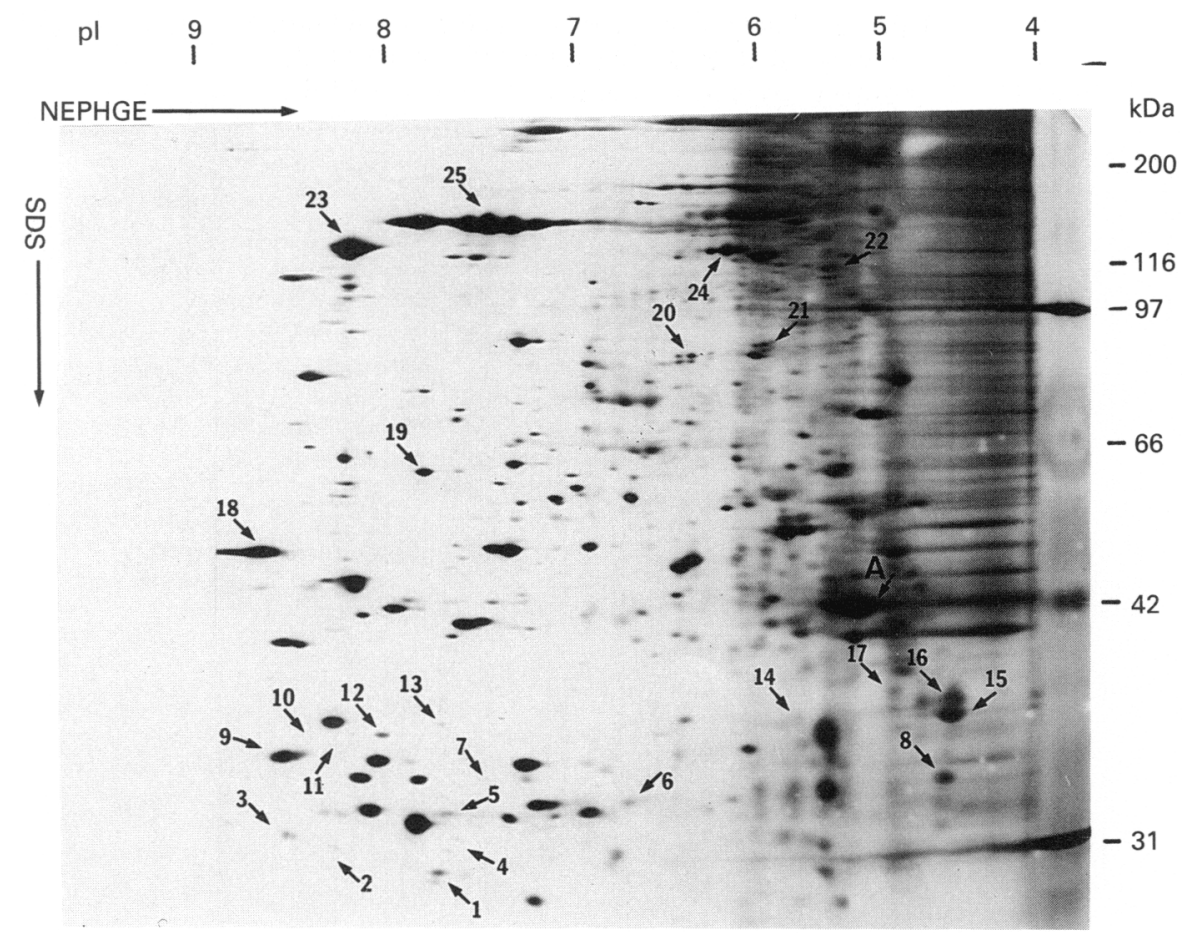

Fig. 5. Oestrous-phase oviductal proteins separated by nonequilibrium $\mathrm{pH}$ gradient electrophoresis (NEPHGE) $\mathrm{pH} 3 \cdot 5-10$. Arrows indicate the proteins that showed cyclic changes. A, actin $\left(M_{\mathrm{r}} 45000\right.$, pI 5·40-5.44).

\section{Discussion}

The primary aim of the present study was to provide a baseline for future work on the specific function of endometrial and oviductal proteins in reproduction. First, we have shown that highresolution two-dimensional SDS-PAGE of protein extracts, even without radioactive labelling, may adequately identify proteins the expression of which changes during the oestrous cycle. Second, relatively small fractions of endometrial and oviductal proteins have been shown to respond to the fluctuation of sex hormones during the normal oestrous cycle. Third, several proteins related to the cycle were shown to be expressed in the same way in the endometrium and in the oviduct; however, many others appeared to be organ specific and were found either in the endometrium or the oviduct. Fourth, more of the proteins specific to the cycle in the endometrium were shown to reach maximal expression during the oestrous than during the dioestrous phase of the cycle. Four of these proteins were found only during oestrus, suggesting that they are synthesized in response to the surge of oestrogens in pro-oestrus (Michael, 1976; DeLeon et al., 1990). Fifth, in the oviduct more proteins were shown to be prominent in dioestrus than oestrus. Finally, two endometrial and seven oviductal proteins were shown to be expressed only in dioestrus. These proteins are probably related to the secondary surge of progesterone (DeLeon et al., 1990). We conclude that the cyclic hormonal changes during the oestrous cycle could be associated with an induction or a suppression of specific proteins, in the endometrium and in the oviduct.

We are not aware of any other systematic studies of mouse endometrial or oviductal proteins that are selectively expressed in various phases of the normal oestrous cycle. Quarmby \& Korach (1984) studied the effects of oestradiol on uterine cells and showed that oestradiol stimulates the synthesis of several proteins, and inhibits the synthesis of others. Our protein number $8\left(M_{\mathrm{r}} 40\right.$, 


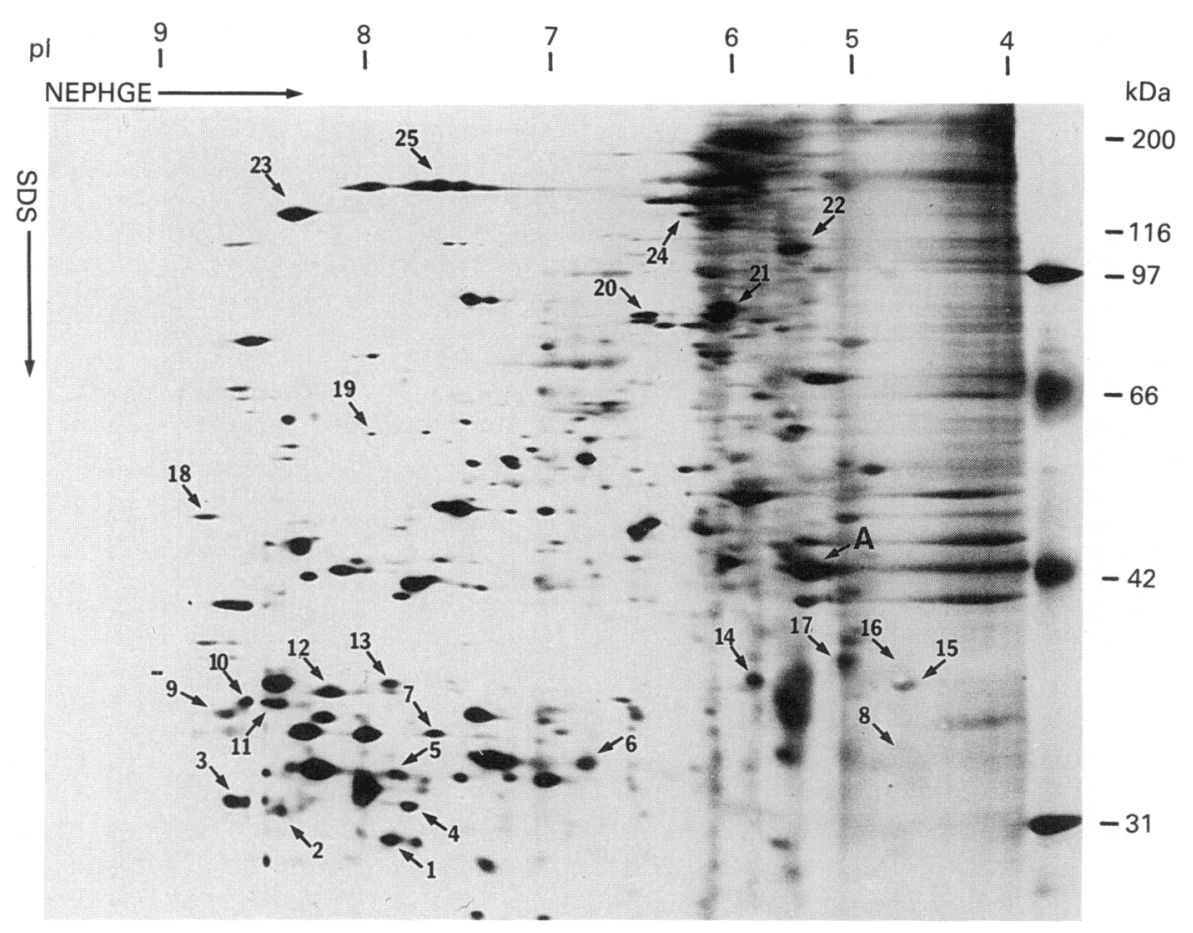

Fig. 6. Dioestrous-phase oviductal proteins separated by nonequilibrium $\mathrm{pH}$ gradient electrophoresis (NEPHGE) pH 3.5-10. Arrows indicate the proteins that showed cyclic changes. Specific cellular proteins: A, actin $\left(M_{\mathrm{r}} 45000, \mathrm{pI} 5 \cdot 40-5 \cdot 44\right)$.

pI 5.25) corresponds to such a protein, the synthesis of which was inhibited by oestradiol in the study of Quarmby \& Korach (1984). Our oestrous phase proteins number 20 and $21\left(M_{\mathrm{r}} 85, \mathrm{pI} 5 \cdot 45\right.$, and $\left.M_{\mathrm{r}} 90, \mathrm{pI} 5 \cdot 20\right)$ also correspond to proteins the synthesis of which was found to be stimulated by oestradiol in the aforementioned study.

The proteins expressed in endometrial cells of mice probably correspond at least in part to some of the proteins found in the rat endometrium. The comparison of our data with those from one-dimensional SDS-PAGE (Umapathysivam \& Jones, 1978) was not feasible because of the differences between the one- and two-dimensional gel electrophoresis. Proteins numbered 12 and 13 from our study have the same properties as proteins labelled 12 and 19 in two-dimensional SDSPAGE of rat uteri by Lejeune et al. (1985). Our protein number $4\left(M_{\mathrm{r}} 35, \mathrm{pI} 5 \cdot 60\right)$, which appears in dioestrus, is probably equivalent to the rat protein number 16 (Lejeune et al., 1985), which is induced by oestrogen and progesterone in epithelial cells. Furthermore, our protein number 26 probably corresponds to the $115 \mathrm{kDa}$ protein described in the rat endometrium by Jacobs \& Lyttle (1987). The synthesis of the $115 \mathrm{kDa}$ protein in the rat endometrium is inhibited by progesterone, which would correspond to our inability to detect it in dioestrus. It is also possible that our protein number $9\left(M_{\mathrm{r}} 41, \mathrm{pI} 5 \cdot 70\right)$ represents the mouse equivalent of the hamster uterine protein of the same molecular weight, described as number 9 by Chaminadas et al. (1989). This protein appears only after combined oestrogen and progesterone treatment of cultured guinea-pig endometrium.

In contrast to the secretory proteins of pregnancy, which presumably mediate implantation of the embryo in the uterus (Weitlauf \& Suda-Hartman, 1988), no specific functions could be assigned a priori to the structural, cytoplasmic hormonally regulated proteins in the mouse uterus described in this study. We plan to study the function of these proteins, to determine the exact cell of origin and investigate the regulation of their synthesis. 
This study was supported in part by USPHS Grants AA-07186 and HD-21355 and the Lalor Foundation, Wilmington, Delaware. The secretarial assistance of Sandra Dixon-Ross is deeply appreciated.

\section{References}

Allen, E. (1922) The oestrus cycle in the mouse. American Journal of Anatomy 30, 297-371.

Bronson, F.H., Dagg, C.P. \& Snell, G.D. (1968) Reproduction. In Biology of the Laboratory Mouse, 2nd edn, pp. 187-204, Staff of the Jackson Laboratory, Dover Publications, New York.

Chaminadas, G., Remy-Martin, J.P., Alkhalaf, M., Propper, A.Y. \& Adessi, G.L. (1989) Effect of progesterone on protein synthesis and secretion by cultured epithelial cells from guinea-pig endometrium. Cell Tissue Research 257, 129-136.

DeLeon, D.D., Zelinski-Wooten, H.B. \& Barkley, M.S. (1990) Hormonal basis of variation on oestrous cyclicity in selected strains of mice. Journal of Reproduction and Fertility 89, 117-126.

Fishel, S.B. (1979) Analysis of mouse uterine proteins at pro-oestrus during early pregnancy and after administration of exogenous steroids. Journal of Reproduction and Fertility 55, 91-100.

Fishel, S.B. (1980) Radiolabelled uterine proteins during early pregnancy and pseudopregnancy in mice after unilateral ovariectomy and superovulation. Journal of Reproduction and Fertility 59, 473-478.

Gore-Langton, E.R. \& Surani, M.A.H. (1976) Uterine luminal proteins of mice. Journal of Reproduction and Fertility 46, 271-274.

Jacobs, M.H. \& Lyttle, C.R. (1987) Uterine media proteins in the rat during gestation. Biology of Reproduction 36, 157-165.

Kapur, R.P. \& Johnson, L.V. (1985) An oviductal fluid glycoprotein associated with ovulated mouse ova and early embryos. Developmental Biology 112, 89-93.

Kapur, R.P. \& Johnson, L.V. (1986) Selective sequestration of an oviductal fluid glycoprotein in the perivitelline space of mouse oocytes and embryos. Journal of Experimental Zoology 238, 249-260.

Kapur, R.P. \& Johnson, L.V. (1988) Ultrastructural evidence that specialized regions of the murine oviduct contribute a glycoprotein to the extracellular matrix of mouse oocytes. Anatomical Record 22, $720-729$.

Laemmli, U.S. (1970) Cleavage of structural proteins during the assembly of the head of bacteriophage T4. Nature 227, 680-685.

Lejeune, B., Lamy, F., Lecocq, R., Deschacht, J. \& Leroy, F. ( 1985 ) Patterns of protein synthesis in endometrial tissues from ovariectomized rats treated with oestradiol and progesterone. Journal of Reproduction and Fertility 73, 223-228.
Lowry, O.H., Rosenbrough, M.J., Farr, A.L. \& Randall, R.J. (195I) Protein measurement with the folin phenol reagent. Journal of Biological Chemistry 93, 265-275.

Michael, S.C. (1976) Plasma prolactin and progesterone during the estrous cycle in the mouse. Proceedings of the Society for Experimental Biology and Medicine 153, 254-257.

Murr, S.M., Geschwind, I.I. \& Bradford, G.E. (1973) Plasma LH and FSH during different oestrous cycle conditions in mice. Journal of Reproduction and Fertility 32, 221-230.

Nieder, G.L. \& Macon, G.F. (1987) Uterine and oviducal protein secretion during early pregnancy in the mouse. Journal of Reproduction and Fertility 81, 287-294.

O'Farrell, P.H. (1975) High resolution two-dimensional electrophoresis of proteins. Journal of Biological Chemistry 250, 4007-4021.

O'Farrell, P.Z., Goodman, H.M. \& O'Farrell, P.H. (1977) High resolution two-dimensional electrophoresis of basic as well as acidic proteins. Cell 6, 1133-1141.

Pentecost, B.T. \& Teng, C.T. (1987) Lactotransferrin is the major estrogen inducible protein of mouse uterine secretions. Journal of Biological Chemistry 262, $10134-10139$.

Putti, R. \& Varano, L. (1979) Histological and histochemical modifications of the uterine and vaginal mucosa of the mouse during the oestrus cycle. Basic and Applied Histochemistry 23, 25-37.

Quarmby, V.E. \& Korach, K.S. (1984) Differential regulation of protein synthesis by estradiol in uterine component tissues. Endocrinology 115, 687-697.

Rugh, R. (1968) The mouse: its reproduction and development, pp. 38-41. Burgess, Minneapolis, USA.

Teng, C.T., Walker, M.P., Bhattacharya, S.N., Klapper, D.G., DiAgustine, R.P. \& McLachlan, J.A. (1986) Purification and properties of an oestrogenstimulated mouse uterine glycoprotein (approx. $70 \mathrm{kD}$ ). Biochemical Journal 240, 413-422.

Umapathysivam, K. \& Jones, W.R. (1978) An investigation of decidual specific proteins in the rat. International Journal of Fertility 23, 138-142.

Weitlauf, H.M. \& Suda-Hartman, M. (1988) Changes in secreted uterine proteins associated with embryo implantation in the mouse. Journal of Reproduction and Fertility 84, 539-549.

Received 27 February 1991 